\title{
Effect of Foliar Application of Plant Growth Regulators on Seasonal Variation in Physiological Behavior in Mango cv. Alphonso
}

\author{
K. V. Malshe*, P. M. Haldankar and S. S. Patil \\ Dr. Balasaheb Sawant Konkan Krishi Vidyapeeth, Dapoli, Dist. Ratnagiri 415702 (MS), India \\ *Corresponding author
}

\section{A B S T R A C T}

\section{Keywords \\ Mango, Alphonso, \\ Plant growth \\ regulators, Gas \\ exchange}

\section{Article Info}

Accepted:

18 May 2020

Available Online:

10 June 2020
The experiment was conducted during the cropping season of 2015-16 and 2016-17 at Department of Horticulture, College of Agriculture, Dapoli, Maharashtra on 35 years old uniform mango (cv. Alphonso) trees with an objective study the effect of plant growth regulators on suppression of post monsoon vegetative flush in mango. In the investigation the physiological behavior of the mango trees were assessed in relation to influence of plant growth regulator sprays. After 24 hours of treatment, the rate of photosynthesis was significantly varied due to foliar application of plant growth regulators. The rate was lowered down than control. Among the treatments, PBZ $2000 \mathrm{ppm}$ treatment showed lowest rate of photosynthesis $\left(6.40 \mu \mathrm{mol} \mathrm{CO}_{2} \mathrm{~m}^{-2} \mathrm{Sec}^{-1}\right)$ and on par with CCC $1500 \mathrm{ppm}$ and $3500 \mathrm{ppm}$ treatments. The control had highest rate of photosynthesis $\left(6.65 \mu \mathrm{mol} \mathrm{CO} \mathrm{CO}_{2}\right.$ $\left.\mathrm{m}^{-2} \mathrm{Sec}^{-1}\right)$. After two weeks of treatment, the rate of photosynthesis was significantly influenced due to treatments of different CCC and PBZ concentration. It was reduced compared to previous readings. The significantly lowest rate $\left(5.30 \mu \mathrm{mol} \mathrm{CO}_{2} \mathrm{~m}^{-2} \mathrm{Sec}^{-1}\right)$ was recorded in CCC $3500 \mathrm{ppm}$ and highest $\left(7.62 \mu \mathrm{mol} \mathrm{CO} \mathrm{C} \mathrm{m}^{-2} \mathrm{Sec}^{-1}\right)$ was in control. The respiration rate after 24 hours of treatment, did not differed significantly during first year but differed significantly in second year and it was significantly highest $(2.37 \mu \mathrm{mol} \mathrm{CO}$ $\left.\mathrm{m}^{-2} \mathrm{Sec}^{-1}\right)$ in PPP $2000 \mathrm{ppm}$ treatment. The lowest rate $\left(2.18 \mu \mathrm{mol} \mathrm{CO} \mathrm{m}^{-2} \mathrm{Sec}^{-1}\right)$ was in PPP $500 \mathrm{ppm}$ ) and $\mathrm{T}_{7}$ (Control) treatments. The pooled data showed non significant effect of plant growth regulators on respiration rate at 24 hours after treatment. At two weeks after treatment, PBZ $2000 \mathrm{ppm}$ treatment had highest respiration rate $\left(2.53 \mu \mathrm{mol} \mathrm{CO} \mathrm{m}^{-2}\right.$ $\left.\mathrm{Sec}^{-1}\right)$ and the lowest rate $\left(2.21 \mu \mathrm{mol} \mathrm{CO} \mathrm{Cm}^{-2} \mathrm{Sec}^{-1}\right)$ was in control. The treatments of CCC were on par among themselves. No significant differences were observed in leaf transpiration rate after 24 hours of treatment. Whereas, it was significantly differed at two weeks after treatment only in the first year. The significantly highest transpiration rate (4.358 $\mu \mathrm{mol} \mathrm{H}_{2} \mathrm{O} \mathrm{m}^{-2} \mathrm{Sec}^{-1}$ ) was recorded in PBZ $2000 \mathrm{ppm}$ treatment and lowest rate (4.358 $\mu \mathrm{mol} \mathrm{H}_{2} \mathrm{O} \mathrm{m}^{-2} \mathrm{Sec}^{-1}$ ) was in control. The stomatal conductance did not differ significantly as reading taken after 24 hours of treatment. At two weeks after treatment, the rate was significantly differed and highest stomatal conductance $\left(0.220 \mu \mathrm{mol} \mathrm{H} \mathrm{H}_{2} \mathrm{O} \mathrm{m}\right.$ $\left.\mathrm{Sec}^{-1}\right)$ was in control and lowest $\left(0.156 \mu \mathrm{mol} \mathrm{H}_{2} \mathrm{O} \mathrm{m}^{-2} \mathrm{Sec}^{-1}\right)$ in CCC $2500 \mathrm{ppm}$ treatment. 


\section{Introduction}

The mango (Mangifera indica L.) is the premier, most celebrated tropical fruit and known as 'King of the fruits' due to its delicious taste, admirable flavour, appealing aroma and attractive colour and other several desirable characters. It is the oldest fruit cultivated in world for over 4000 years. Mango has intimate association with religious, cultural, aesthetic and economical values since from long time and therefore it the national fruit of India. It is the most popular tropical fruit from Anacardiaceae family originated from South East Asia, the Indo-Burma region.

India has the richest wealth of mango germplasm consisting of more than thousands of varieties growing all over the country. Among the popular cultivars, 'Alphonso' ranks tops and acclaimed as the best Indian mango variety. This cultivar is commercially grown in west coast of India comprising Maharashtra, Goa, Karnataka and Gujarat states.

Lack of environmental signals for mango flowering being a limiting factor for obtaining consistent production especially in Alphonso cultivar. In mango crop, the phenomenon of flowering and fruiting is complex. Davenport and Nunez-Elisea (1997) has described the conceptual model of mango flowering to simplify the interaction of external and internal factors responsible for regulating vegetative and reproductive shoot initiation and induction in mango trees in the tropical and subtropical environments. The flowering in mango is largely influenced by the biochemical constituents present in the floral stimuli at bud break stage. Further, the maturity of terminal shoots and the carbohydrate accumulation in leaves as well as shoot apex are also certainly associated with the synthesis of the floral stimulus in mango trees. The productivity improvement in current farming system is extensively depends on manipulation of the physiological processes of the crop by chemical means. In commercial mango plantations, it is advantageous to control the vegetative growth to attain regular, early and uniform flowering. Plant growth retardants like paclobutrazol, cycocel, etc. are synthetic compounds normally used to retard the shoot growth in a desired way without altering the developmental patterns of plants. These plant growth regulator alter the physiological processes in plants and gas exchange study can help to assess the response of crop in relation to physiological changes. The present investigation was therefore proposed to study the trend in physiological behavior (Gas exchange) of mango cv. Alphonso as influenced by sprays of plant growth regulators.

\section{Materials and Methods}

The experiment was conducted during the cropping season of 2015-16 and 2016-17 at Department of Horticulture, College of Agriculture, Dapoli, Maharashtra on 35 years old uniform mango (cv. Alphonso) trees with an objective study the effect of plant growth regulators on suppression of post monsoon vegetative flush in mango. The experiment was laid out in randomized block design with three replications and seven treatments viz., $\mathrm{T}_{1}$ - CCC- $1500 \mathrm{ppm}, \mathrm{T}_{2}$ - CCC- $2500 \mathrm{ppm}, \mathrm{T}_{3}$ - CCC-3500 ppm, T 4 - PBZ -500 ppm, T 5 - PBZ -1000 ppm, T 6 - PBZ- 2000 ppm, T 7 - Control (No foliar application of PGR). Foliar application of plant growth regulators and nutrients was made at two stages. In the first experiment, the foliar application of PGRs was done in month of September, first spray$1^{\text {st }}$ fortnight of September and second spray$2^{\text {nd }}$ fortnight of September as given in treatment details. In the second experiment, two sprays were taken in each treatment, $1^{\text {st }}$ 
spray immediately after emergences of new vegetative flush and second 15 days after first spray. The data on gas exchange parameters viz, rate of photosynthesis and respiration, rate of transpiration and stomatal conductance were recorded at three stages i.e. before foliar spraying of plant growth regulators, after 24 hours of treatments and at two weeks after treatments. All these physiological parameters were measured by using artificial light source between $10: 00$ to $12: 00$ by portable photosynthesis system (LICOR 6400xt, Loc. Inc. USA) in photon flux density (PFD) value $500 \mu$ mol-mol-2 s-1 and using the healthy third or fourth leaf of the mango cv. Alphonso. The experimental data were analyzed according the procedure described by Panse and Sukhatme (1985).

\section{Results and Discussion}

The data pertaining to various gas exchange parameters viz, rate of photosynthesis and respiration, rate of transpiration and stomatal conductance was recorded at three stages i.e. before foliar spraying of plant growth regulators, after 24 hours of treatments and at two weeks after treatments are presented in Table 1 to 4.

\section{Rate of leaf photosynthesis}

Photosynthesis is fundamental process and photosynthesis rate can be regulated by plant growth regulators by activating secondary messengers that play a crucial role in increasing the enzymatic activity of the plant.

The data on rate of leaf photosynthesis are presented in Table 1 and depicted with Fig. 6. Before imposing the plant growth regulators treatments, the rate of leaf photosynthesis did not differ significantly during both the years. In the present study, it was noticed that no significant variations among the photosynthesis and respiration rate were noticed before the treatments of CCC and PBZ. The photosynthesis rate was remarkably reduced down in plant growth regulators treatments than the control. The rate of photosynthesis was lowered down from prior to imposing of treatments to 24 hours after treatments and two weeks after treatments. The inverse trend was observed in case of respiration rate.

After 24 hours of treatment, the rate of photosynthesis was significantly varied due to foliar application of plant growth regulators and it was lowered down than control. An overall reduction in rate of photosynthesis was observed after 24 hours of treatments exposure as compared to rate of photosynthesis before exposure of the treatments except control. In the first year, the lowest rate of photosynthesis $\left(6.29 \mu \mathrm{mol} \mathrm{CO}_{2}\right.$ $\mathrm{m}^{-2} \mathrm{Sec}^{-1}$ ) was observed in $\mathrm{T}_{3}$ (CCC 3500 ppm). The highest rate (6. $29 \mu \mathrm{mol} \mathrm{CO} \mathrm{Cm}^{-2}$ $\left.\mathrm{Sec}^{-1}\right)$ was in control $\left(\mathrm{T}_{7}\right)$ followed by $\mathrm{T}_{4}(6$. $\left.47 \mu \mathrm{mol} \mathrm{CO}_{2} \mathrm{~m}^{-2} \mathrm{Sec}^{-1}\right)$. The rest of the treatments were on par with each other. In second year, the rate was lowest $(6.46 \mu \mathrm{mol}$ $\mathrm{CO}_{2} \mathrm{~m}^{-2} \mathrm{Sec}^{-1}$ ) in $\mathrm{T}_{6}$ (PBZ $2000 \mathrm{ppm}$ ) which was on par with $\mathrm{T}_{1}$ (6. $52 \mu \mathrm{mol} \mathrm{CO}_{2} \mathrm{~m}^{-2}$ $\left.\mathrm{Sec}^{-1}\right)$. The rest of growth regulator treatments were on par with each other. The highest rate of leaf photosynthesis (6. $75 \mu \mathrm{mol} \mathrm{CO}_{2} \mathrm{~m}^{-2}$ $\mathrm{Sec}^{-1}$ ) was in control. The pooled data indicated that treatment PBZ $2000 \mathrm{ppm}\left(\mathrm{T}_{6}\right)$ showed lowest rate of photosynthesis (6. 40 $\mu \mathrm{mol} \mathrm{CO} \mathrm{Cm}^{-2} \mathrm{Sec}^{-1}$ ) which was on par with CCC 1500 ppm and 3500 ppm treatments. The control had highest rate of photosynthesis (6. $65 \mu \mathrm{mol} \mathrm{CO}_{2} \mathrm{~m}^{-2} \mathrm{Sec}^{-1}$ ).

After two weeks of treatment, the rate of leaf photosynthesis was reduced compared to previous readings except in control where it was found increased. The data presented in Table 1 revealed that the rate of photosynthesis was significantly influenced due to treatments of different CCC and PBZ 
concentration. The lowest rates $(5.21 \mu \mathrm{mol}$ $\mathrm{CO}_{2} \mathrm{~m}^{-2} \mathrm{Sec}^{-1}$ and $5.31 \mu \mathrm{mol} \mathrm{CO} \mathrm{Cm}^{-2} \mathrm{Sec}^{-1}$ ) were recorded by PBZ 2000 ppm $\left(\mathrm{T}_{6}\right)$ during first year and by CCC $3500 \mathrm{ppm}\left(\mathrm{T}_{3}\right)$ in second year. The pooled analysis showed that CCC $3500 \mathrm{ppm}\left(\mathrm{T}_{3}\right)$ had lowest rates (5.30 $\left.\mu \mathrm{mol} \mathrm{CO} \mathrm{Cm}^{-2} \mathrm{Sec}^{-1}\right)$ and the rest of treatments were on par with each other. The highest rate (7.62 $\mu \mathrm{mol} \mathrm{CO}_{2} \mathrm{~m}^{-2} \mathrm{Sec}^{-1}$ ) was in control.

Neluheni (2004) suggested that the rate of photosynthesis is apparently associated with favourable environmental condition such as optimum sunshine, humidity, temperature with lower transpo-evaporative demand. Urban et al., (2004) studied $\mathrm{CO}_{2}$ assimilation rate which supports the present findings. Rakshe (2011) has attempted to study the photosynthesis rate of mango during flowering season.

\section{Rate of respiration}

The rate of respiration before the plant growth regulator treatments did not vary significantly during both the years. After 24 hours of treatment, there was no significant difference in the respiration rate during first year. But in second year, the respiration rate was significantly highest $\left(2.37 \mu \mathrm{mol} \quad \mathrm{CO}_{2} \mathrm{~m}^{-2}\right.$ $\left.\mathrm{Sec}^{-1}\right)$ in PPP $2000 \mathrm{ppm}\left(\mathrm{T}_{6}\right)$ treatment. The lowest rate $\left(2.18 \mu \mathrm{mol} \mathrm{CO}_{2} \mathrm{~m}^{-2} \mathrm{Sec}^{-1}\right)$ was in $\mathrm{T}_{4}$ (PPP $500 \mathrm{ppm}$ ) and $\mathrm{T}_{7}$ (Control) treatments. The pooled data showed the non significant effect of plant growth regulators on respiration rate at 24 hours after treatment (Table 2).

At two weeks after treatment, the rate of respiration showed the significant variation. During the first year, the highest rate of respiration $\left(2.37 \mu \mathrm{mol} \mathrm{CO} \mathrm{Cm}^{-2} \mathrm{Sec}^{-1}\right)$ was in PPP 2000 ppm $\left(\mathrm{T}_{6}\right)$ treatment and it was closely followed by $\mathrm{T}_{2}$ and $\mathrm{T}_{5}$. The lowest respiration rate $\left(2.20 \mu \mathrm{mol} \mathrm{CO}_{2} \mathrm{~m}^{-2} \mathrm{Sec}^{-1}\right)$ was recorded in control $\left(\mathrm{T}_{7}\right)$. In the second year, PPP 2000 ppm (T6) treatment again registered the highest respiration rate $(2.62$ $\mu \mathrm{mol} \mathrm{CO}_{2} \mathrm{~m}^{-2} \mathrm{Sec}^{-1}$ ) followed by $\mathrm{T}_{3}, \mathrm{~T}_{5}$ and $\mathrm{T}_{1}$. The lowest rate $\left(2.21 \mu \mathrm{mol} \mathrm{CO} \mathrm{m}^{-2} \mathrm{Sec}^{-1}\right)$ was in control followed by $\mathrm{T}_{4}$ (PBZ 500 $\mathrm{ppm})$. The pooled analysis exhibited almost parallel results and PPP $2000 \mathrm{ppm}\left(\mathrm{T}_{6}\right)$ treatment again registered the highest respiration rate $\left(2.53 \mu \mathrm{mol} \mathrm{CO}_{2} \mathrm{~m}^{-2} \mathrm{Sec}^{-1}\right)$ followed by $\mathrm{T}_{5}$. The treatments of CCC were on par with each other and the lowest rate (2.21 $\mu \mathrm{mol} \mathrm{CO} \mathrm{CO}^{-2} \mathrm{Sec}^{-1}$ ) was in control.

Urban et al., (2004) opined that the increase in mitochondrial respiration or decrease in partial pressure of carbon dioxide in intercellular space has direct negative influence on photosynthesis rate.

\section{Rate of transpiration}

The data pertaining to the leaf transpiration rate are presented in Table 3, further revealed that no significant differences were observed before the treatment and after 24 hours of treatment during both the years of investigation.

However, the rate was significantly differed at two weeks after treatment only during first year. The significantly highest transpiration rate $\left(4.358 \mu \mathrm{mol} \mathrm{H}_{2} \mathrm{O} \mathrm{m}^{-2} \mathrm{Sec}^{-1}\right)$ was recorded in PPP $2000 \mathrm{ppm}\left(\mathrm{T}_{6}\right)$ treatment and lowest rate $\left(4.358 \mu \mathrm{mol} \mathrm{H}_{2} \mathrm{O} \mathrm{m} \mathrm{mec}^{-1}\right.$ ) was in control which was at par with $\mathrm{T}_{4}$. The treatments of CCC were on par with each other.

\section{Stomatal conductance}

The data regarding stomatal conductance recorded at three different stages are presented in Table 4. The stomatal conductance did not differ significantly at reading taken before the treatment and after 24 hours of treatment. 
Table.1 Effect of foliar application of plant growth regulators on rate of photosynthesis in mango cv. Alphonso

\begin{tabular}{|c|c|c|c|c|c|c|c|c|c|c|}
\hline \multirow{3}{*}{\multicolumn{2}{|c|}{ Treatments }} & \multicolumn{9}{|c|}{ Rate of photosynthesis $\left(\mu \mathrm{mol} \mathrm{CO}_{2} \mathrm{~m}^{-2} \mathrm{Sec}^{-1}\right)$} \\
\hline & & \multicolumn{3}{|c|}{ Before the treatment } & \multicolumn{3}{|c|}{ After 24 hours of treatment } & \multicolumn{3}{|c|}{ After 2 weeks of treatment } \\
\hline & & 2015 & 2016 & $\begin{array}{c}\text { Pooled } \\
\text { mean }\end{array}$ & 2015 & 2016 & $\begin{array}{c}\text { Pooled } \\
\text { mean }\end{array}$ & 2015 & 2016 & $\begin{array}{c}\text { Pooled } \\
\text { mean }\end{array}$ \\
\hline $\mathbf{T}_{1}$ & CCC- 1500 ppm & 6.55 & 6.67 & 6.61 & 6.34 & 6.52 & 6.43 & 5.24 & 5.39 & 5.32 \\
\hline $\mathbf{T}_{2}$ & CCC- 2500 ppm & 6.48 & 6.72 & 6.60 & 6.35 & 6.54 & 6.45 & 5.44 & 5.41 & 5.43 \\
\hline $\mathbf{T}_{\mathbf{3}}$ & CCC-3500 ppm & 6.57 & 6.80 & 6.69 & 6.29 & 6.57 & 6.43 & 5.29 & 5.31 & 5.30 \\
\hline $\mathbf{T}_{4}$ & PBZ -500 ppm & 6.54 & 6.73 & 6.64 & 6.47 & 6.66 & 6.56 & 6.19 & 6.14 & 6.16 \\
\hline $\mathbf{T}_{5}$ & PBZ -1000 ppm & 6.46 & 6.82 & 6.64 & 6.38 & 6.68 & 6.53 & 5.32 & 5.59 & 5.46 \\
\hline $\mathbf{T}_{6}$ & PBZ- 2000 ppm & 6.52 & 6.63 & 6.57 & 6.33 & 6.46 & 6.40 & 5.21 & 5.45 & 5.33 \\
\hline $\mathbf{T}_{7}$ & Control (No foliar application of PGR) & 6.53 & 6.71 & 6.62 & 6.55 & 6.75 & 6.65 & 7.65 & 7.59 & 7.62 \\
\hline \multicolumn{2}{|c|}{ Mean } & 6.52 & 6.73 & 6.62 & 6.39 & 6.60 & 6.49 & 5.76 & 5.84 & 5.80 \\
\hline \multicolumn{2}{|c|}{ S. E.m \pm} & $\mathbf{0 . 0 3 0}$ & 0.061 & 0.042 & 0.024 & 0.053 & 0.029 & 0.069 & 0.099 & 0.060 \\
\hline \multicolumn{2}{|c|}{ C.D. at $5 \%$} & NS & NS & NS & 0.074 & 0.162 & 0.084 & 0.212 & 0.300 & 0.176 \\
\hline
\end{tabular}


Table.2 Effect of foliar application of plant growth regulators on rate of respiration in mango cv. Alphonso

\begin{tabular}{|c|c|c|c|c|c|c|c|c|c|c|}
\hline \multirow{3}{*}{\multicolumn{2}{|c|}{ Treatments }} & \multicolumn{9}{|c|}{ Rate of respiration $\left(\mu \mathrm{mol} \mathrm{CO}_{2} \mathrm{~m}^{-2} \mathrm{Sec}^{-1}\right)$} \\
\hline & & \multicolumn{3}{|c|}{ Before the treatment } & \multicolumn{3}{|c|}{$\begin{array}{c}\text { After } 24 \text { hours of } \\
\text { treatment }\end{array}$} & \multicolumn{3}{|c|}{ After 2 weeks of treatment } \\
\hline & & 2015 & 2016 & $\begin{array}{c}\text { Pooled } \\
\text { mean }\end{array}$ & 2015 & 2016 & $\begin{array}{c}\text { Pooled } \\
\text { mean }\end{array}$ & 2015 & 2016 & $\begin{array}{c}\text { Pooled } \\
\text { mean }\end{array}$ \\
\hline $\mathbf{T}_{1}$ & CCC- 1500 ppm & 2.15 & 2.24 & 2.19 & 2.20 & 2.28 & 2.24 & 2.31 & 2.52 & 2.42 \\
\hline $\mathbf{T}_{2}$ & CCC- 2500 ppm & 2.21 & 2.18 & 2.19 & 2.24 & 2.23 & 2.24 & 2.44 & 2.38 & 2.41 \\
\hline $\mathbf{T}_{\mathbf{3}}$ & CCC-3500 ppm & 2.13 & 2.23 & 2.18 & 2.19 & 2.31 & 2.25 & 2.32 & 2.56 & 2.44 \\
\hline $\mathbf{T}_{4}$ & PBZ -500 ppm & 2.18 & 2.15 & 2.17 & 2.20 & 2.18 & 2.19 & 2.27 & 2.26 & 2.26 \\
\hline $\mathbf{T}_{5}$ & PBZ -1000 ppm & 2.27 & 2.24 & 2.26 & 2.32 & 2.28 & 2.30 & 2.43 & 2.50 & 2.46 \\
\hline $\mathbf{T}_{6}$ & PBZ- 2000 ppm & 2.13 & 2.28 & 2.20 & 2.17 & 2.37 & 2.27 & 2.45 & 2.62 & 2.53 \\
\hline $\mathbf{T}_{7}$ & Control (No foliar application of PGR) & 2.21 & 2.18 & 2.20 & 2.19 & 2.18 & 2.19 & 2.20 & 2.21 & 2.21 \\
\hline \multicolumn{2}{|c|}{ Mean } & 2.18 & 2.21 & 2.20 & 2.22 & 2.26 & 2.24 & 2.35 & 2.44 & 2.39 \\
\hline \multicolumn{2}{|c|}{ S. E.m \pm} & 0.041 & 0.049 & 0.032 & 0.041 & 0.047 & 0.031 & 0.049 & 0.048 & 0.034 \\
\hline \multicolumn{2}{|c|}{ C.D. at $5 \%$} & NS & NS & NS & NS & 0.145 & NS & 0.152 & 0.149 & 0.098 \\
\hline
\end{tabular}


Table.3 Effect of foliar application of plant growth regulators on rate of transpiration in mango cv. Alphonso

\begin{tabular}{|c|c|c|c|c|c|c|c|c|c|c|}
\hline \multirow{3}{*}{\multicolumn{2}{|c|}{ Treatments }} & \multicolumn{9}{|c|}{ Rate of transpiration $\left(\mu \mathrm{mol} \mathrm{H}_{2} \mathrm{O} \mathrm{m}^{-2} \mathrm{Sec}^{-1}\right)$} \\
\hline & & \multicolumn{3}{|c|}{ Before the treatment } & \multicolumn{3}{|c|}{ After 24 hours of treatment } & \multicolumn{3}{|c|}{ After 2 weeks of treatment } \\
\hline & & \multirow{2}{*}{\begin{tabular}{|l|}
2015 \\
3.669
\end{tabular}} & \multirow{2}{*}{\begin{tabular}{|l|}
2016 \\
3.611
\end{tabular}} & \multirow{2}{*}{$\begin{array}{c}\begin{array}{c}\text { Pooled } \\
\text { mean }\end{array} \\
3.640 \\
\end{array}$} & \multirow{2}{*}{\begin{tabular}{|l|}
2015 \\
3.690
\end{tabular}} & \multirow{2}{*}{\begin{tabular}{|l|}
2016 \\
3.653
\end{tabular}} & \multirow{2}{*}{$\begin{array}{c}\begin{array}{c}\text { Pooled } \\
\text { mean }\end{array} \\
3.672\end{array}$} & \multirow{2}{*}{\begin{tabular}{|l|}
2015 \\
4.189
\end{tabular}} & \multirow{2}{*}{\begin{tabular}{|l|}
2016 \\
4.207 \\
\end{tabular}} & \multirow{2}{*}{$\begin{array}{c}\begin{array}{c}\text { Pooled } \\
\text { mean }\end{array} \\
4.198 \\
\end{array}$} \\
\hline $\mathbf{T}_{1}$ & CCC- 1500 ppm & & & & & & & & & \\
\hline $\mathbf{T}_{2}$ & CCC- 2500 ppm & 3.529 & 3.562 & 3.546 & 3.573 & 3.613 & 3.593 & 4.268 & 3.988 & 4.128 \\
\hline $\mathbf{T}_{\mathbf{3}}$ & CCC-3500 ppm & 3.701 & 3.641 & 3.671 & 3.733 & 3.693 & 3.713 & 4.276 & 4.259 & 4.267 \\
\hline $\mathbf{T}_{4}$ & PBZ -500 ppm & 3.776 & 3.610 & 3.693 & 3.800 & 3.611 & 3.706 & 4.014 & 3.710 & 3.862 \\
\hline $\mathbf{T}_{\mathbf{5}}$ & PBZ -1000 ppm & 3.625 & 3.752 & 3.688 & 3.680 & 3.713 & 3.696 & 4.136 & 3.999 & 4.067 \\
\hline $\mathbf{T}_{6}$ & PBZ- 2000 ppm & 3.805 & 3.465 & 3.635 & 3.918 & 3.486 & 3.702 & 4.358 & 3.936 & 4.147 \\
\hline $\mathbf{T}_{7}$ & Control (No foliar application of PGR) & 3.643 & 3.839 & 3.741 & 3.613 & 3.800 & 3.707 & 3.995 & 3.908 & 3.952 \\
\hline \multicolumn{2}{|c|}{ Mean } & 3.678 & 3.640 & 3.659 & 3.715 & 3.653 & 3.684 & 4.177 & 4.001 & 4.089 \\
\hline \multicolumn{2}{|c|}{ S. E.m \pm} & 0.150 & 0.158 & 0.108 & 0.135 & 0.157 & 0.104 & 0.091 & 0.182 & 0.102 \\
\hline \multicolumn{2}{|c|}{ C.D. at 5\% } & NS & NS & NS & NS & NS & NS & 0.280 & NS & NS \\
\hline
\end{tabular}


Table.4 Effect of foliar application of plant growth regulators on stomatal conductance in mango cv. Alphonso

\begin{tabular}{|c|c|c|c|c|c|c|c|c|c|c|}
\hline \multirow{3}{*}{\multicolumn{2}{|c|}{ Treatments }} & \multicolumn{9}{|c|}{ Stomatal conductance $\left(\mu \mathrm{mol} \mathrm{H}_{2} \mathrm{O} \mathrm{m}^{-2} \mathrm{Sec}^{-1}\right)$} \\
\hline & & \multicolumn{3}{|c|}{ Before the treatment } & \multicolumn{3}{|c|}{$\begin{array}{l}\text { After } 24 \text { hours of } \\
\text { treatment }\end{array}$} & \multicolumn{3}{|c|}{ After 2 weeks of treatment } \\
\hline & & 2015 & 2016 & $\begin{array}{c}\text { Pooled } \\
\text { mean }\end{array}$ & 2015 & 2016 & $\begin{array}{l}\text { Pooled } \\
\text { mean }\end{array}$ & 2015 & 2016 & $\begin{array}{c}\text { Pooled } \\
\text { mean }\end{array}$ \\
\hline $\mathbf{T}_{1}$ & CCC- 1500 ppm & 0.251 & 0.225 & 0.238 & 0.247 & 0.223 & 0.235 & 0.171 & 0.141 & 0.156 \\
\hline $\mathbf{T}_{2}$ & CCC- 2500 ppm & 0.271 & 0.211 & 0.241 & 0.268 & 0.208 & 0.238 & 0.180 & 0.140 & 0.160 \\
\hline $\mathbf{T}_{\mathbf{3}}$ & CCC-3500 ppm & 0.249 & 0.242 & 0.246 & 0.242 & 0.237 & 0.240 & 0.181 & 0.175 & 0.178 \\
\hline $\mathbf{T}_{4}$ & PBZ -500 ppm & 0.247 & 0.232 & 0.240 & 0.248 & 0.232 & 0.240 & 0.193 & 0.197 & 0.195 \\
\hline $\mathbf{T}_{5}$ & PBZ -1000 ppm & 0.251 & 0.239 & 0.245 & 0.244 & 0.234 & 0.239 & 0.182 & 0.151 & 0.167 \\
\hline $\mathbf{T}_{6}$ & PBZ- 2000 ppm & 0.253 & 0.251 & 0.252 & 0.245 & 0.271 & 0.258 & 0.161 & 0.169 & 0.165 \\
\hline $\mathbf{T}_{7}$ & Control (No foliar application of PGR) & 0.262 & 0.248 & 0.255 & 0.261 & 0.249 & 0.255 & 0.228 & 0.208 & 0.220 \\
\hline \multicolumn{2}{|c|}{ Mean } & 0.255 & 0.235 & 0.245 & 0.251 & 0.236 & 0.244 & 0.185 & 0.169 & 0.177 \\
\hline \multicolumn{2}{|c|}{ S. E.m \pm} & 0.014 & 0.012 & 0.090 & 0.013 & 0.015 & 0.010 & 0.008 & 0.011 & 0.007 \\
\hline \multicolumn{2}{|c|}{ C.D. at $5 \%$} & NS & NS & NS & NS & NS & NS & 0.024 & 0.035 & 0.020 \\
\hline
\end{tabular}


Fig.1 Effect of foliar application of plant growth regulators on rate of photosynthesis in mango cv. Alphonso

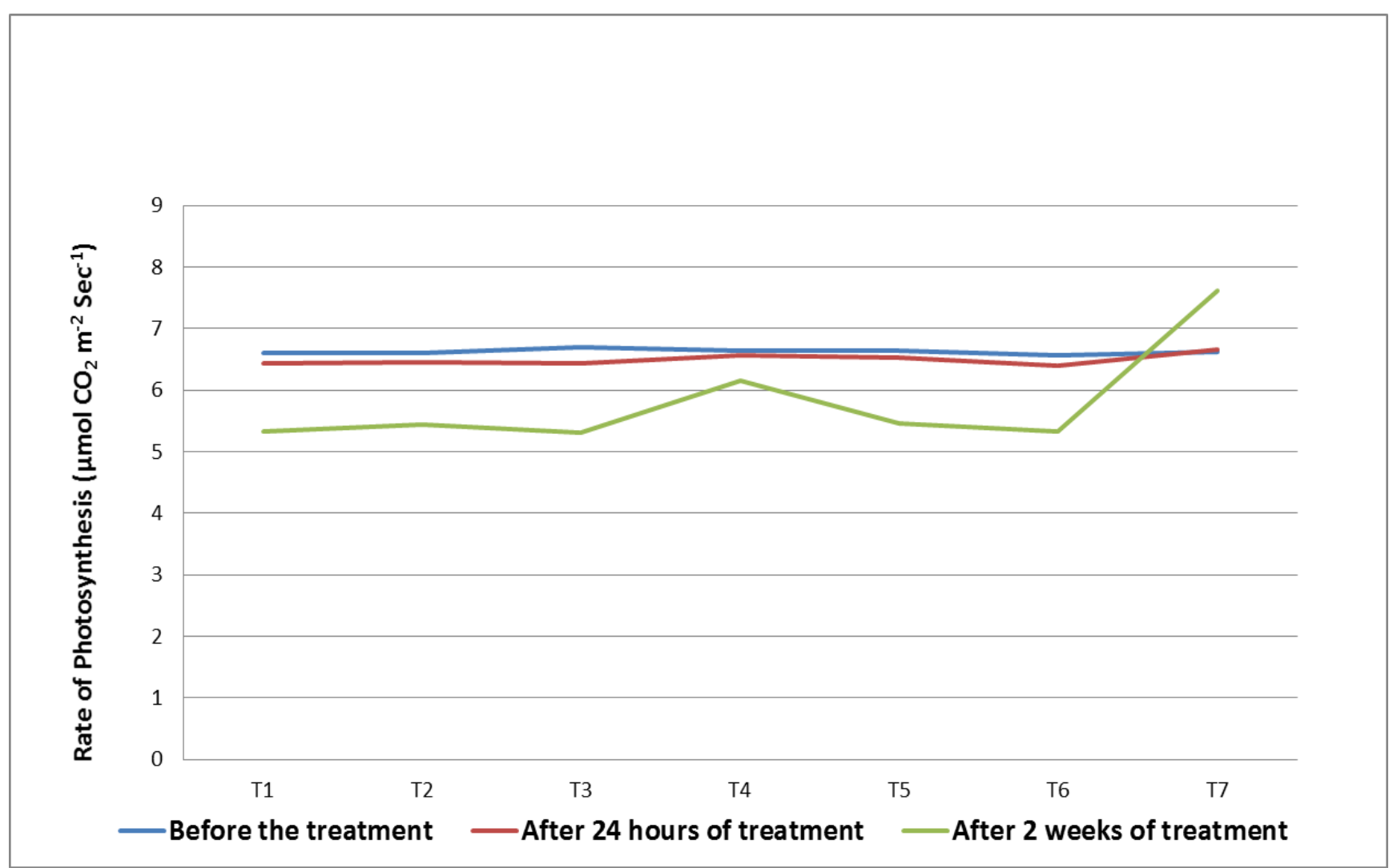

Legend: $\mathrm{T}_{1}$ - CCC- $1500 \mathrm{ppm}, \mathrm{T}_{2}$ - CCC- $2500 \mathrm{ppm}, \mathrm{T}_{3}$ - CCC-3500 ppm, $\mathrm{T}_{4}$ - PBZ -500 ppm, $\mathrm{T}_{5}$ - PBZ -1000 ppm, $\mathrm{T}_{6}$ - PBZ- 2000 ppm , $\mathrm{T}_{7}$ - Control (No foliar application of PGR) 
Fig.2 Effect of foliar application of plant growth regulators on rate of respiration in mango cv. Alphonso

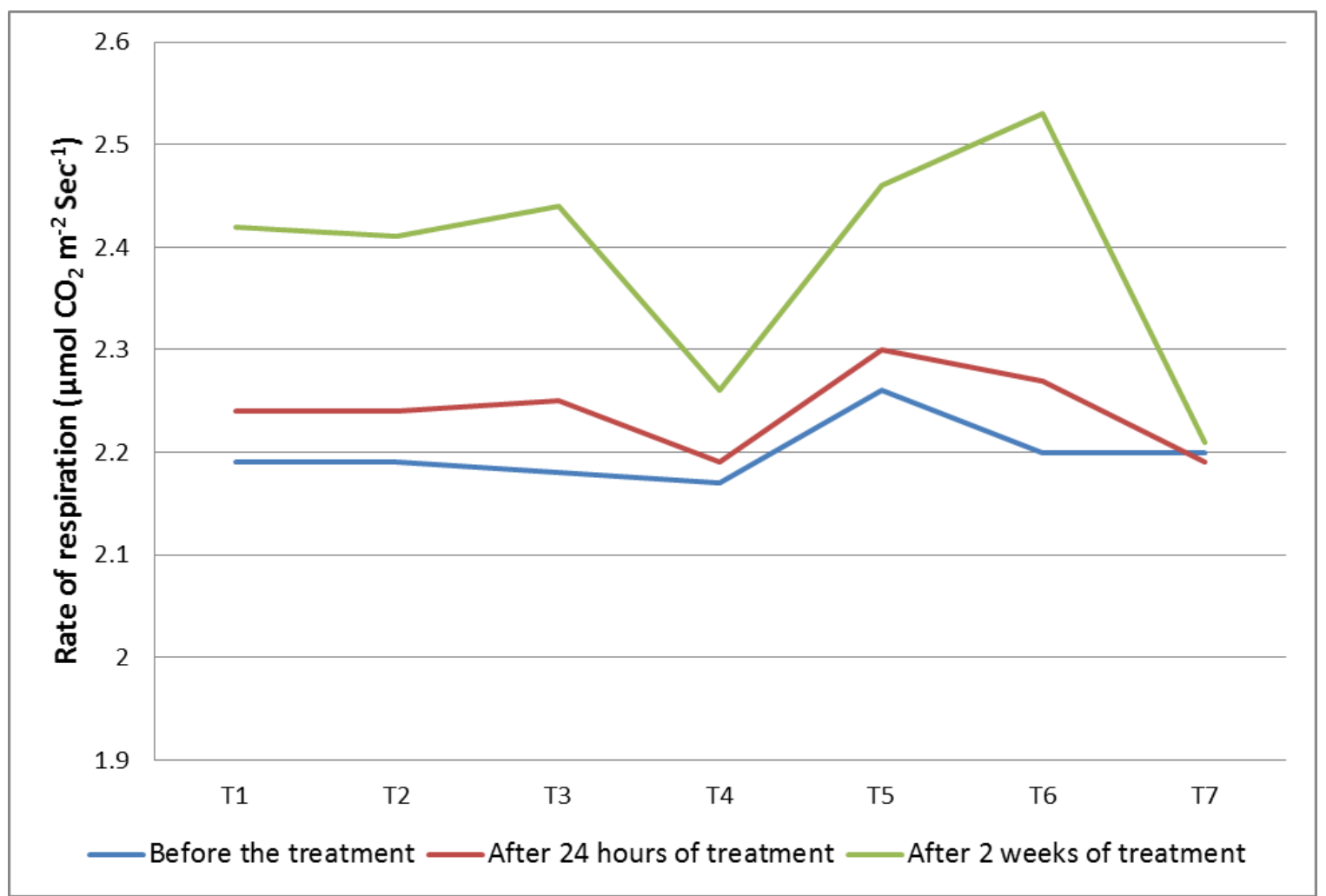

Legend: $\mathrm{T}_{1}$ - CCC- $1500 \mathrm{ppm}, \mathrm{T}_{2}$ - CCC- $2500 \mathrm{ppm}, \mathrm{T}_{3}$ - CCC-3500 ppm, $\mathrm{T}_{4}$ - PBZ -500 ppm, $\mathrm{T}_{5}$ - PBZ -1000 ppm, $\mathrm{T}_{6}$ - PBZ- 2000 ppm, $\mathrm{T}_{7}$ - Control (No foliar application of PGR) 
Fig.3 Effect of foliar application of plant growth regulators on rate of transpiration in mango cv. Alphonso

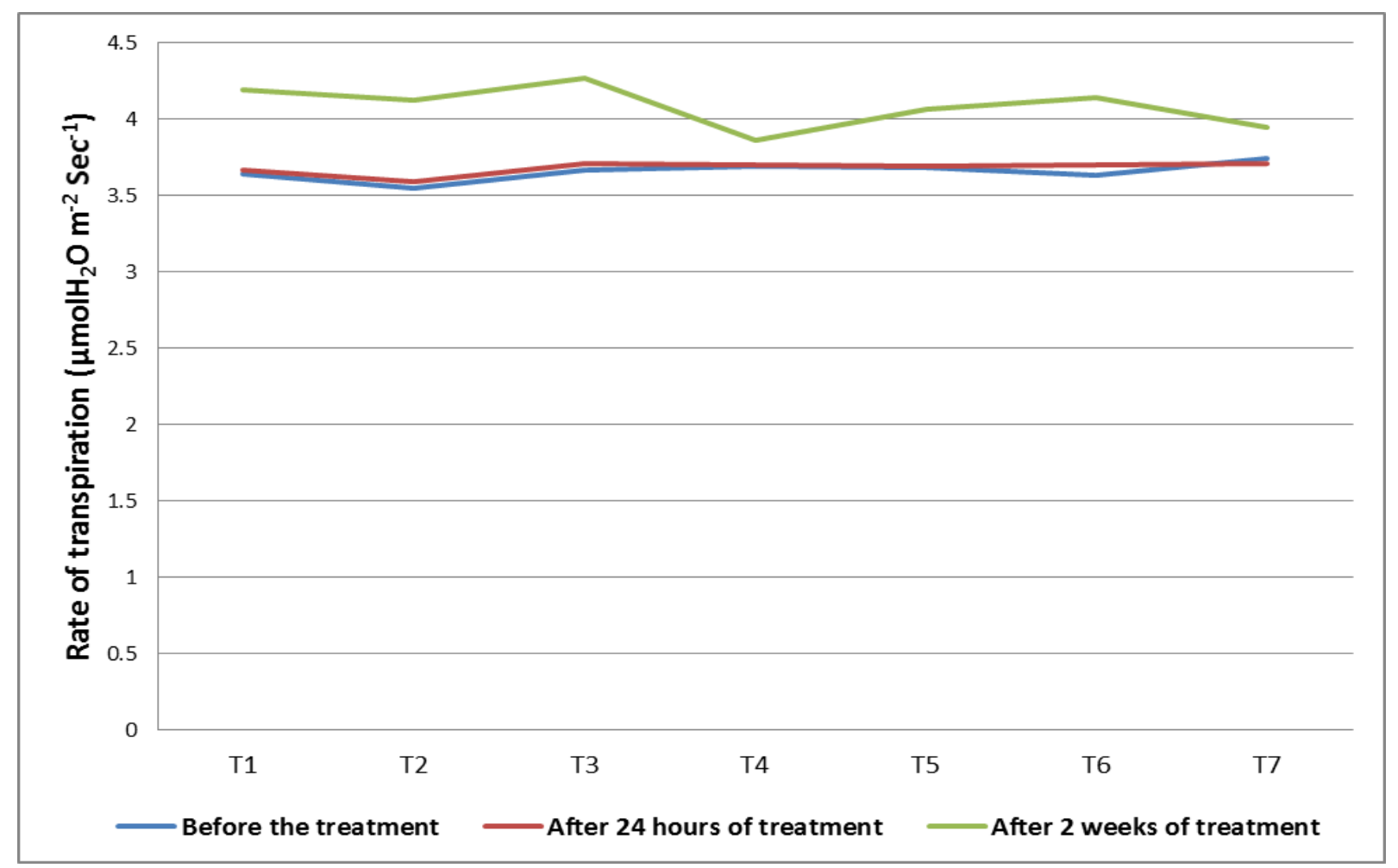


Fig.4 Effect of foliar application of plant growth regulators on stomatal conductance in mango cv. Alphonso

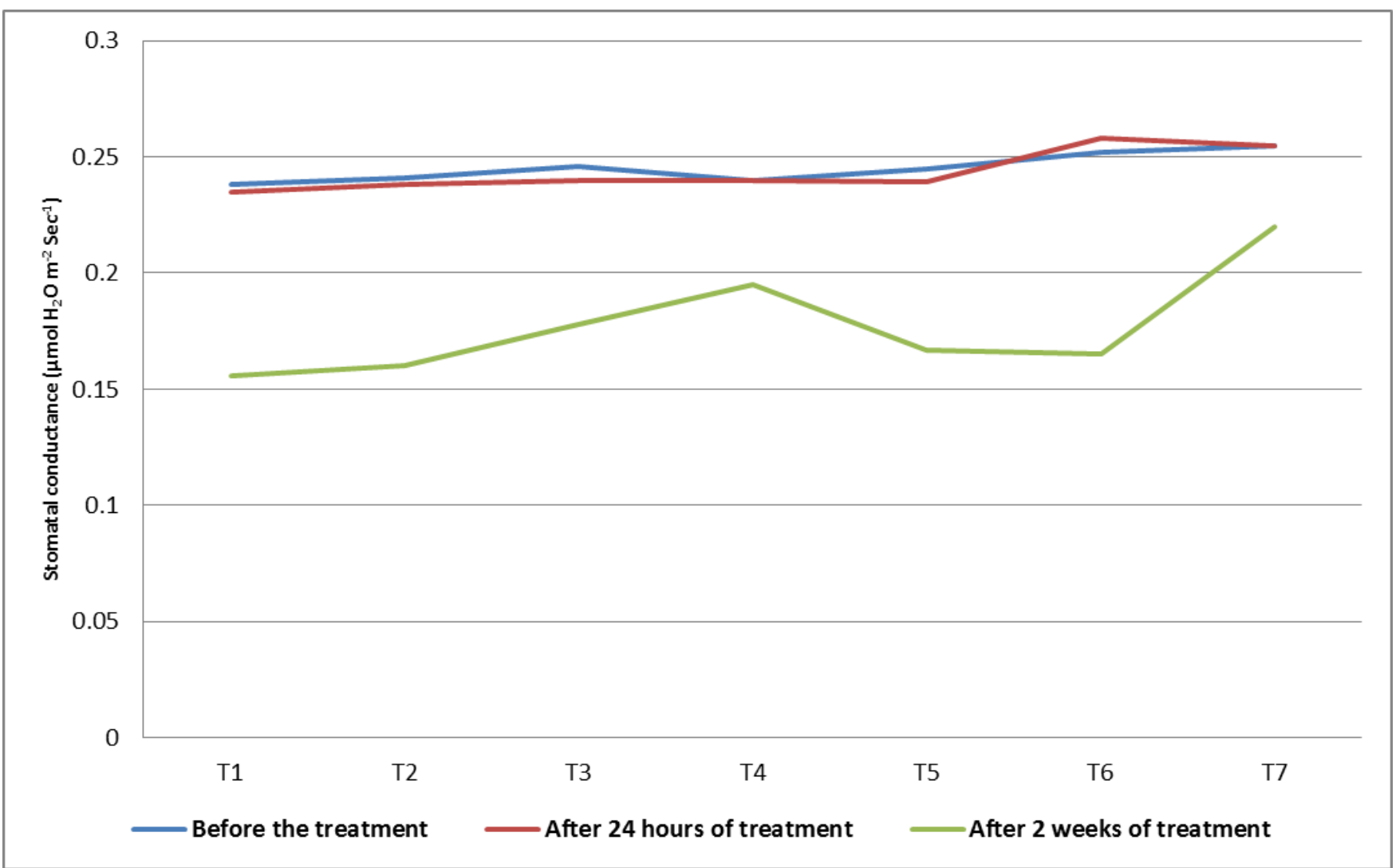

Legend: $\mathrm{T}_{1}$ - CCC- $1500 \mathrm{ppm}, \mathrm{T}_{2}$ - CCC- $2500 \mathrm{ppm}, \mathrm{T}_{3}$ - CCC-3500 ppm, $\mathrm{T}_{4}$ - PBZ -500 ppm, $\mathrm{T}_{5}$ - PBZ -1000 ppm, $\mathrm{T}_{6}$ - PBZ- 2000 ppm, $\mathrm{T}_{7}$ - Control (No foliar application of PGR) 
At two weeks after treatment, the rate was significantly differed and during both the years, the stomatal conductance was highest (0.228 and $0.208 \mu \mathrm{mol} \mathrm{H}_{2} \mathrm{O} \mathrm{m}^{-2} \mathrm{Sec}^{-1}$, respectively) in control $\left(\mathrm{T}_{7}\right)$ and lowest $(0.161$ $\left.0.208 \mu \mathrm{mol} \mathrm{H}_{2} \mathrm{O} \mathrm{m}^{-2} \mathrm{Sec}^{-1}\right)$ in PPP $2000 \mathrm{ppm}$ treatment (First year) and $\left(0.140 \mu \mathrm{mol} \mathrm{H}_{2} \mathrm{O}\right.$ $\left.\mathrm{m}^{-2} \mathrm{Sec}^{-1}\right)$ in CCC $2500 \mathrm{ppm}$ treatment (Second year). The pooled data indicates highest value $\left(0.220 \mu \mathrm{mol} \mathrm{H}_{2} \mathrm{O} \mathrm{m}^{-2} \mathrm{Sec}^{-1}\right)$ in control $\left(\mathrm{T}_{7}\right)$ and lowest $\left(0.156 \mu \mathrm{mol} \mathrm{H}_{2} \mathrm{O} \mathrm{m}^{-2}\right.$ $\left.\mathrm{Sec}^{-1}\right)$ in CCC $2500 \mathrm{ppm}\left(\mathrm{T}_{1}\right)$ treatment.

The transpiration and stomatal conductance in any plant cell are the important physiological measures to assess the plant water relationship (Terryl et al., 1989). The stomatal conductance is linked with high leaf temperature and consequently increased transpiration per stomatal conductance unit (Condon et al., 2002).

As per the earlier reports, plant growth retardants in general and paclobutrazol in particular, which is thousand times more powerful than cycocel and has ability to maintain high water potential of treated plants than that of untreated plants (Wieland and Wample, 1985 and Burondkar, 2005). The lower values to some extent was obtained for transpiration and stomatal conductance could be attributed to the rainy season when relative humidity is always very high (above $85 \%$ ) in Konkan region. Rakshe (2011) and Burondkar et al., (2012) studied the transpiration rate and stomatal conductance in mango. Bhalerao (2013) also assessed the stomatal conductance of mango which supported the present findings.

The findings of present experiment only indicated the fact and same experiment need to be continued to validate the relationship of phtranspiration and stomatal conductance in mango with vegetative flush and flowering as in photosynthesis and respiration.

\section{References}

Bhalerao, R. R. 2013, Flowering and fruiting behavior with respect of nutrients and carbohydrate status in mango cv. Alphonso and Kesar. Thesis submitted to Navsari Agril. University, Navsari, Gujrat.

Burondkar, M. M., Pujari, K. H., Shinde, K. A. and Bhave, S. G. 2012. Seasonal variation in physiological behaviour of Alphonso mango, under konkan conditions. J. Agril. Res. Tech. 37(1): 51-54.

Burondkar, M. M. 2005. Influence of plant growth regulators, polyamine and nutritents on post flowring physiological behaviour in relation to yield and quality in Alphonso mango (Mangifera indica L.). Ph. D. Thesis. University of Agricultural Sciences, Dharwad, Karnataka.

Condon, A. G., Richards, R. A., Rebetzke, G. J., and Farquhar, G. D. 2002. Improving intrinsic water use efficiency and crop yield. Crop Science 42: 122-131.

Davenport, T. L, Nunez -Elisea R. 1997, Reproductive physiology. In: Litz, R.E. (ed.) The Mango: Botany, Production and Uses. CAB International, Wallingford, Oxon, UK, pp. 69-146. Goguey, T., 1993, Study of effect of three flowering inducing substances on Kent and Zill mango. Acta Hort. 341: 216-224.

Neluheni, K. O. 2004, Seasonal pattern of vegetative growth and photosynthesis in mango (Mangefera indica L.) trees. Master's Thesis, University of Pretoria, South Africa.

Panse, V.G. and Sukhatme, P.V., 1985, Statistical methods for agricultural workers. Indian Council of Agricultural Research, New Delhi, pp.167-174.

Rakshe, M. V. 2011, Physiological studies on effect of stem girdling, root pruning and 
chemical treatments on induction of flowering in Alphonso mango (Mangifera indica L.). M. Sc. (Agri.) Thesis submitted to Dr. B. S. Konkan Krishi Vidyapeeth, Dapoli, Maharashtra 415712.

Terryl, R., Roper and Larry, E. Williams, 1989, Net $\mathrm{CO}_{2}$ assimilation and cabohydrade partioning of Grapevine leaves in response to trunk girdling and gibberllic acid application. Plant
Physiology, 89: 1136-1140.

Urban. L., Lu, P. and Thibaud, R. 2004. Inhibitory effect of flowering and early fruit growth on leaf photosynthesis in mango. Tree Physiology. 24: 387-399.

Wieland, W. F. and Wample, L. R. 1985, Effects of paclobutrazol on growth, photosynthesis and carbohydrates content of delicious apples. Sci. Hortic., $26: 139-147$.

\section{How to cite this article:}

Malshe, K. V., P. M. Haldankar and Patil, S. S. 2020. Effect of Foliar Application of Plant Growth Regulators on Seasonal Variation in Physiological Behavior in Mango cv. Alphonso. Int.J.Curr.Microbiol.App.Sci. 9(06): 1629-1642. doi: https://doi.org/10.20546/ijcmas.2020.906.201 